Research Paper

\title{
Internationalisation Processes Developing Sector of High Technology in the European Union: Cluster Analysis
}

\author{
Nikolaj Ambrusevic \\ Corresponding author: nikamb@ism.lt \\ ISM University of Management and Economics, Lithuania \\ Henley Business School, University of Reading, United Kingdom \\ nikolajambrusevic.ambrusevic@henley.ac.uk
}

\section{About the author}

Nikolaj Ambrusevic is an experienced educator lecturing Marketing, Management, International Business and Economics. Nikolaj holds a PhD in Economics and has two Master's, in Business Administration and in International Law. He works as an Associate Professor at several higher education institutions in his home country, Lithuania, and is a visiting lecturer at Henley Business School at the University of Reading, United Kingdom. Previously, he worked for multinational and global market intelligence companies specializing in technology, automotive, travel, construction, oil \& gas mining, and other industrial verticals across CEE \& CIS countries. He is the author of multiple articles and proceedings at international conferences and investigates the internationalisation process of high technology development.

\section{Abstract}

The author of the paper aims at discovering the main patterns in order to evaluate the impact of the internationalisation process of high technology development in the context of social, economic and technological progress, and to develop and prove that the suggested methodology is necessary to assess the importance of specific social, economic and technological changes. Main theories explaining the development process of the high technology sector are analysed here. Theoretical suggestion is also discussed to use the combination of the human development index and other economical factors in order to measure a country's abilities in high technology sector development in EU. Cluster and multicriteria analyses are used for examination in this study, too. As a result, the author determines the main aspects defining the assessment of importance of certain processes of internationalisations on industrial, business, national and international levels of the process of high technology development.

Keywords:Internationalisation, High technology development, Human development index, Sector of high technology, Cluster analysis 


\section{Introduction}

Many economists and scientists agree that the sector of high technology is the long term driver of economic growth, and national economies flourish when societies create conditions in which new sources of wealth and work are created. It is a well-known fact that innovative companies of the sector of high technology gain a larger market share, add more value and create more new jobs than other companies. Nowadays the major trends in high technology sector development may be characterised by increased scope of globalisation and, as result, information exchange, rapid scientific changes and diffusion of new technologies, forced by new customer preferences.

Despite the importance of the high technology development, the European Union is facing a big challenge here. When it comes to technological innovation, Europe is now lagging behind not only the US and Japan, but also China (Tsanova and Havenith, 2019). Thus, the clear understanding and evaluation of main trends related to the development of the sector of high technology and supporting international competition in innovation processes becomes extremely important.

The goal of the paper is to develop a theoretical model based upon the application of the methodology of complex evaluation of the process of development of the sector of high technology, designated for economic solutions, revealing the importance of academic society.

Methodology of research includes the analysis of scientific literature, the systematic review of scientific statements and empirical research results, comparison and synthesis. The main method applied in the paper is of logical and analytical character based on the analysis of the current situation enabling setting the main theoretical guidelines for performance evaluation methodology developing the high technology sector. Empirical studies conducted on the basis of the systems approach performing the correlation and regression analysis, cluster analysis, and multicriteria analysis.

\section{Meaning of the Internationalisation Process in the Globalised World}

Regarding J. Enders (2004) the terms of 'internationalisation' and 'globalisation' became popular in the beginning of the last decated of the XX century. There is a heated debate on describing the processes of internationalisation and the concept of globalisation in scientific literature nowadays. According to some authors, these are identical concepts expressing varying degrees of unification of the world economy or its individual spheres (Enders, 2004; Ball, Lindsay and Rose, 2008). Other authors tend to differentiate the meanings and highlight that the processes of internationalisation must be treated as a set of measures to achieve the level of globalisation in a particular area (Leask, 2009).

Currently, the scientific literature is focused on the following aspects of internationalisation processes:

- internationalisation processes in the context of globalisation (Wach, 2014);

- implementation of measures to promote internationalisation processes;

- internationalisation processes in the context of technological advances; 
- internationalisation processes that promote international trade;

- activities of multinational companies and their influence on internationalisation processes;

- activities of transnational organisations promoting the internationalisation of national markets.

Although the vast majority of scientists and economists in economic theory and practice agree on the inevitability of globalisation of the world economy (Park, 2001; Salter, 2009), the process of examining economic internationalisation reveals aspects that some authors assign to threats and challenges, and others - to natural forms of international economic cooperation. The main forms of economic internationalisation are being distinguished regarding two main criteria for their assessment:

- The involvement of public authorities in the global economy in a global context (Mayer and Ottaviano, 2008);

- The social nature of internationaliSation processes as a result of international economic trends (Longhi and Nijkamp, 2007; Watt, 2009).

\section{Impact of the Processes of Internationalisation on High Technology Sector Development}

High-tech issues attracted the attention of researchers five decades ago in order to find new ways to increase the competitiveness of globalised economy. The research of Hymer (1960), Vernon (1966), Dunning (1977) and Johanson \& Vahnne (1977) is significant for this period of time. The results of these studies allowed the sector of high technology to be defined as an industry whose development is characterised by an element of internationalisation and orientation towards international trade. Authors of subsequent research papers such as D'Avenie (1994), Roberts and Malone (1996), Carayannis, Rogers, Kurihara and Allbritton (1998), Loane (2005), Carter and Jones-Evans (2006), highlighted the most effective directions for high-tech development: industrial innovation and additional funding for its commercialisation.

The challenges and demands posed by internationalisation processes might be seen at different levels of the modern economy, and it is therefore appropriate to examine the development of the sector of high technology in three ways:

- On a global scale, where the impact of the sector of high technology affects all economic and social aspects, and its valuation is significant in predicting global trends;

- On an industrial level, while assessing the impact of the sector of high technology in different regions of the world;

- On a national level, when identifying the importance of the sector of high technology for a particular country. 


\section{Empirical Research Methodology: Cluster Analysis}

The process of evaluation of the sector of high technology in an example of the European Union consist of two parts.

The first part is dedicated to the distinguishing main economic and social factors having impact on countries' performances developing sector of high technology. By using COPRAS multicriteria evaluation (Podvezko, 2011) following set of alternative criteria has been raised:

a) expenditure on research and development (percentage of GDP);

b) expenditure on social protection (percentage of GDP);

c) share of GERD (Gross domestic expenditure on R\&D) financed by business enterprise sector (percentage of GDP);

d) share of GERD financed by government sector (percentage of GDP);

e) share of GERD on higher education sector (percentage of GDP);

f) research and development personnel (as percentage of total labour force);

g) persons employed in science and technology (as percentage of active population).

The second part of the research is dedicated to reveal the impact of chosen economic and social criteria on main aspects defining the process of the development of the sector of high technology. The process of the development of the sector of high technology splits into four stages here: 1) industrial level, characterised by the number of community design applications to the EUIPO (European Union Intellectual Property Office) per mln. inhabitants; 2) business level, characterised by the number of innovative enterprises as a share of all enterprises in the country; 3) national level, characterised by the innovation turnover as a share of total turnover; and 4) international level, focused on the exports of medium- and high-technology products as a share of total product exports. The methodology of variation of economic phenomena based of correlation analysis and dispersion calculation is in use here.

It is assumed, that the complex evaluation of the aspects defining the process of the development of the sector of high technology will confirm that the improved innovative capacity in terms of patent applications, growing number of innovative enterprises and their productivity contributes to the high performance of a country on international level in terms of increasing exports of medium- and high-technology products.

\section{Results of Empirical Research}

Cluster analysis based on revealing the spaces of human development index has identified four groups of countries within the European Union.

Each group of the countries may be identified regarding the average level of the index and the value of Gross Domestic Product per capita.

Regarding the results the first cluster includes Ireland, Germany, Sweden, the Netherlands, Denmark, 
Table 1 Clusters Based on HDI and Average GDP Per Capita Data

\begin{tabular}{|c|c|c|}
\hline Country & Human Development Index & GDP per capita, USD \\
\hline Ireland & 0.938 & 78,785 \\
\hline Germany & 0.936 & 52,559 \\
\hline Sweden & 0.933 & 52,984 \\
\hline Netherlands & 0.931 & 56,383 \\
\hline Denmark & 0.929 & 52,121 \\
\hline United Kingdom & 0.922 & 45,705 \\
\hline Finland & 0.920 & 46,430 \\
\hline Belgium & 0.916 & 48,245 \\
\hline Austria & 0.908 & 52,137 \\
\hline Luxembourg & 0.904 & 106,705 \\
\hline France & 0.901 & 45,775 \\
\hline Slovenia & 0.896 & 36,746 \\
\hline Spain & 0.891 & 40,139 \\
\hline Czech Republic & 0.888 & 37,371 \\
\hline Italy & 0.880 & 39,637 \\
\hline Malta & 0.878 & 45,606 \\
\hline Estonia & 0.871 & 34,096 \\
\hline Greece & 0.870 & 29,123 \\
\hline Cyprus & 0.867 & 39,973 \\
\hline Poland & 0.865 & 31,939 \\
\hline Lithuania & 0.858 & 34,826 \\
\hline Slovakia & 0.855 & 35,130 \\
\hline Latvia & 0.847 & 29,901 \\
\hline Portugal & 0.847 & 32,006 \\
\hline Hungary & 0.838 & 31,903 \\
\hline Croatia & 0.831 & 26,221 \\
\hline Bulgaria & 0.813 & 23,156 \\
\hline Romania & 0.811 & 26,447 \\
\hline
\end{tabular}

Sources: United Nations Development Programme Human development report 2018, International Monetary Fund

the United Kingdom, Finland, Belgium, Austria, Luxembourg, and France; second - Slovenia, Spain, Czech Republic, Italy, Malta, Estonia, Greece, Cyprus, and Poland; third - Lithuania, Slovakia, Latvia, Portugal, and Hungary; fourth cluster - Croatia, Bulgaria, and Romania.

The calculation has shown that the results of the cluster analysis have the greatest impact on the number of innovative enterprises, which defines the business level of the development of the sector of high technology (determination coefficient 0.64). Therefore, the research revealed that the variation of the index space is appropriate for predictions regarding one parameter characterising the development of the sector of high 
Table 2 Comparison of Clusters HDI and Average GDP per Capita Data

\begin{tabular}{|l|l|l|l|l|}
\hline $\begin{array}{c}\text { Cluster (number } \\
\text { of countries) }\end{array}$ & HDI frames & $\begin{array}{c}\text { Average GDP } \\
\text { per capita, USD }\end{array}$ & $\begin{array}{c}\text { Minimal GDP } \\
\text { per capita, USD }\end{array}$ & $\begin{array}{l}\text { Maximal GDP } \\
\text { per capita, USD }\end{array}$ \\
\hline $1(11)$ & 0.922 & 57,984 & 45,705 & 106,705 \\
\hline $2(9)$ & 0.878 & 37,181 & 29,123 & 45,606 \\
\hline $3(5)$ & 0.849 & 32,753 & 29,901 & 35,130 \\
\hline $4(3)$ & 0.818 & 25,275 & 23,156 & 26,447 \\
\hline
\end{tabular}

Table 3 Evaluation of Dependence of High Technology Sector Development Factors on Cluster Features (Prepared by Author)

\begin{tabular}{|c|c|c|c|c|c|c|c|c|c|}
\hline 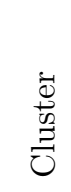 & 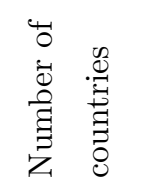 & 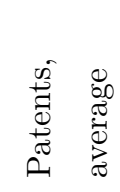 & 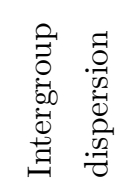 & 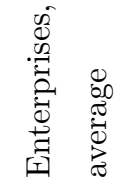 & 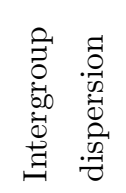 & 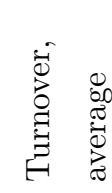 & 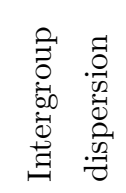 & 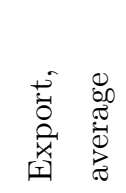 & 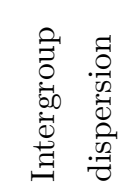 \\
\hline 1 & 11 & 56.55 & 2178.98 & 58.88 & 25.57 & 11.57 & 21.15 & 53.82 & 42.59 \\
\hline 2 & 9 & 32.44 & 506.25 & 39.39 & 88.11 & 10.14 & 16.41 & 51.98 & 169.10 \\
\hline 3 & 5 & 13.60 & 43.84 & 36.04 & 122.67 & 10.36 & 25.23 & 49.20 & 261.61 \\
\hline 4 & 3 & 8.67 & 36.22 & 26.20 & 148.82 & 5.40 & 45.34 & 42.10 & 267.23 \\
\hline \multicolumn{2}{|c|}{$\begin{array}{l}\text { General } \\
\text { dispersion }\end{array}$} & \multicolumn{2}{|r|}{1370} & \multicolumn{2}{|r|}{214.24} & \multicolumn{2}{|r|}{26.16} & \multicolumn{2}{|r|}{158.90} \\
\hline \multicolumn{2}{|c|}{$\begin{array}{l}\text { Determination } \\
\text { coefficient }\end{array}$} & \multicolumn{2}{|r|}{0.25} & \multicolumn{2}{|r|}{0.64} & \multicolumn{2}{|r|}{0.12} & \multicolumn{2}{|r|}{0.08} \\
\hline \multicolumn{2}{|c|}{$\begin{array}{l}\text { Empirical } \\
\text { correlation } \\
\text { ratio }\end{array}$} & \multicolumn{2}{|r|}{0.4978} & \multicolumn{2}{|r|}{0.8027} & \multicolumn{2}{|r|}{0.3505} & \multicolumn{2}{|r|}{0.2801} \\
\hline
\end{tabular}

technology in the European Union: the number of the innovative enterprises (empirical correlation ratio $0.8027)$.

In order to establish alternative aspects, important for the evaluation of the development of the sector of high technology in the European Union, COPRAS multicriteria analysis was in use.

where:

a) expenditure on research and development (percentage of GDP);

b) expenditure on social protection (percentage of GDP);

c) share of GERD financed by business enterprise sector (percentage of GDP);

d) share of GERD financed by government sector (percentage of GDP);

e) share of GERD on higher education sector (percentage of GDP); 
f) research and development personnel (as percentage of total labour force);

g) persons employed in science and technology (as percentage of active population).

Table 4 The Comparison of EU Countries' High Technology Sector Factors (Prepared by Author)

\begin{tabular}{|c|c|c|c|c|c|c|c|c|c|}
\hline Countries & a) & b) & c) & d) & e) & f) & g) & $\begin{array}{c}\text { Relative } \\
\text { significance }\end{array}$ & Rating \\
\hline Weights & 0.25 & 0.15 & 0.20 & 0.05 & 0.05 & 0.15 & 0.15 & & \\
\hline Belgium & 2.49 & 19.6 & 58.6 & 22.5 & 2.0 & 1.67 & 22.4 & 0.0445567 & 6 \\
\hline Bulgaria & 0.96 & 12.5 & 43.6 & 21.8 & 0.1 & 0.71 & 18.7 & 0.0301735 & 16 \\
\hline Czech Republic & 1.93 & 12.0 & 39.5 & 35.6 & 0.8 & 1.33 & 25.2 & 0.0359149 & 12 \\
\hline Denmark & 2.87 & 22.4 & 59.4 & 29.4 & 0.0 & 2.18 & 18.1 & 0.0517844 & 2 \\
\hline Germany & 2.94 & 19.4 & 65.2 & 28.5 & - & 1.62 & 30.5 & 0.0528665 & 1 \\
\hline Estonia & 1.49 & 13.0 & 48.2 & 37.6 & 0.3 & 0.91 & 25.5 & 0.0337873 & 15 \\
\hline Ireland & 1.18 & 9.5 & 48.4 & 25.9 & 1.5 & 1.33 & 16.2 & 0.0295481 & 20 \\
\hline Greece & 0.99 & 19.4 & 40.2 & 42.6 & 2.3 & 1.03 & 10.1 & 0.0267201 & 24 \\
\hline Spain & 1.19 & 16.6 & 46.7 & 40.0 & 4.4 & 0.96 & 16.6 & 0.0295566 & 19 \\
\hline France & 2.22 & 24.3 & 55.7 & 34.6 & 1.0 & 1.48 & 23.7 & 0.0440712 & 7 \\
\hline Croatia & 0.84 & 14.3 & 42.9 & 41.4 & 4.8 & 0.65 & 13.1 & 0.0261226 & 25 \\
\hline Italy & 1.29 & 20.9 & 52.1 & 35.2 & 0.9 & 1.15 & 17.6 & 0.0342141 & 14 \\
\hline Cyprus & 0.50 & 13.0 & 34.9 & 41.1 & 4.6 & 0.36 & 14.1 & 0.0232173 & 26 \\
\hline Latvia & 0.62 & 11.7 & 21.6 & 47.7 & 2.9 & 0.57 & 26.4 & 0.0222678 & 27 \\
\hline Lithuania & 1.04 & 11.2 & 39.0 & 39.2 & 2.4 & 0.82 & 23.9 & 0.0267586 & 23 \\
\hline Luxembourg & 1.24 & 18.4 & 47.1 & 47.7 & 1.6 & 1.86 & 32.2 & 0.0385340 & 10 \\
\hline Hungary & 1.36 & 14.0 & 56.4 & 26.2 & - & 0.89 & 19.1 & 0.0351460 & 13 \\
\hline Malta & 0.77 & 11.3 & 54.5 & 33.4 & 1.3 & 0.66 & 26.6 & 0.0282824 & 21 \\
\hline Netherlands & 2.03 & 15.9 & 52.0 & 31.3 & 0.1 & 1.57 & 20.2 & 0.0410174 & 9 \\
\hline Austria & 3.09 & 20.5 & 53.1 & 30.4 & 0.0 & 1.76 & 25.6 & 0.0513535 & 3 \\
\hline Poland & 1.00 & 16.4 & 53.1 & 38.9 & 2.4 & 0.85 & 20.8 & 0.0296218 & 18 \\
\hline Portugal & 1.27 & 17.4 & 44.4 & 42.6 & 3.7 & 1.11 & 16.2 & 0.0297631 & 17 \\
\hline Romania & 0.49 & 11.7 & 49.4 & 39.6 & 1.1 & 0.37 & 6.7 & 0.0201952 & 28 \\
\hline Slovenia & 2.20 & 16.2 & 69.2 & 20.2 & 0.4 & 1.46 & 17.3 & 0.0439611 & 8 \\
\hline Slovakia & 1.18 & 14.5 & 46.2 & 41.0 & 1.9 & 0.70 & 18.1 & 0.0277851 & 22 \\
\hline Finland & 2.75 & 24.9 & 57.0 & 28.9 & 0.4 & 1.86 & 20.1 & 0.0495332 & 5 \\
\hline Sweden & 3.25 & 20.2 & 61.0 & 28.3 & 0.9 & 1.69 & 24.9 & 0.0509485 & 4 \\
\hline United Kingdom & 1.69 & 15.2 & 51.8 & 26.3 & 1.4 & 1.32 & 22.4 & 0.0364340 & 11 \\
\hline Total & & & & & & & & 1,000000 & \\
\hline
\end{tabular}


Table 5 Comparison of EU Countries High Technology Sector Development Criteria

\begin{tabular}{|c|c|c|c|c|c|c|c|c|}
\hline $\begin{array}{l}\text { Criteria of high } \\
\text { technology } \\
\text { sector } \\
\text { development }\end{array}$ & \multicolumn{2}{|c|}{$\begin{array}{l}\text { Community } \\
\text { design } \\
\text { applications to the } \\
\text { EUIPO per } \\
\text { million population }\end{array}$} & \multicolumn{2}{|c|}{$\begin{array}{l}\text { Number of } \\
\text { innovative } \\
\text { enterprises as a } \\
\text { share of all } \\
\text { enterprises }(\%)\end{array}$} & \multicolumn{2}{|c|}{$\begin{array}{l}\text { Innovation } \\
\text { turnover as a } \\
\text { share of total } \\
\text { turnover }(\%)\end{array}$} & \multicolumn{2}{|c|}{$\begin{array}{l}\text { Exports of medium- } \\
\text { and high-technology } \\
\text { products as a share of } \\
\text { total product exports } \\
(\%)\end{array}$} \\
\hline Countries: & result & place & result & place & result & place & result & place \\
\hline Belgium & 33 & 11 & 64.2 & 3 & 7.6 & 17 & 48.8 & 18 \\
\hline Bulgaria & 17 & $19-21$ & 26.1 & 24 & 4.8 & 26 & 32.1 & 27 \\
\hline Czech Republic & 21 & 17 & 42.0 & 17 & 14.6 & 6 & 64.9 & 5 \\
\hline Denmark & 80 & 3 & 49.5 & 13 & 7.0 & 18 & 48.3 & 20 \\
\hline Germany & 40 & 9 & 67.0 & 1 & 13.3 & 7 & 68.0 & 3 \\
\hline Estonia & 29 & 13 & 26.5 & 23 & 10.5 & 13 & 44.0 & 21 \\
\hline Ireland & 16 & 22 & 61.0 & 4 & 18.1 & 3 & 52.6 & 14 \\
\hline Greece & 6 & $26-27$ & 51.0 & 12 & 12.8 & 8 & 22.5 & 28 \\
\hline Spain & 20 & 18 & 36.4 & 21 & 15.9 & 4 & 48.4 & 19 \\
\hline France & 25 & $15-16$ & 56.4 & 7 & 15.0 & 5 & 59.2 & 7 \\
\hline Croatia & 6 & $26-27$ & 39.7 & 20 & 4.9 & 25 & 39.3 & 23 \\
\hline Italy & 30 & 12 & 48.7 & 14 & 10.1 & 14 & 52.6 & 13 \\
\hline Cyprus & 17 & $19-21$ & 41.8 & 18 & 4.5 & 27 & 59.6 & 6 \\
\hline Latvia & 25 & $15-16$ & 25.5 & 26 & 5.3 & 24 & 35.1 & 26 \\
\hline Lithuania & 10 & 23 & 43.3 & 16 & 8.6 & 16 & 35.3 & 25 \\
\hline Luxembourg & 194 & 1 & 65.1 & 2 & 6.5 & $20-21$ & 50.6 & 15 \\
\hline Hungary & 7 & 25 & 25.6 & 25 & 12.5 & 9 & 70.3 & 1 \\
\hline Malta & 89 & 2 & 41.2 & 19 & 4.1 & 28 & 70.1 & 2 \\
\hline Netherlands & 45 & 7 & 55.3 & $8-9$ & 10.8 & 12 & 48.9 & 17 \\
\hline Austria & 50 & 6 & 59.5 & 6 & 12.0 & 11 & 57.8 & 9 \\
\hline Poland & 39 & 10 & 21.0 & 27 & 6.4 & 22 & 49.6 & 16 \\
\hline Portugal & 17 & $19-21$ & 54.0 & 11 & 6.3 & 23 & 37.7 & 24 \\
\hline Romania & 3 & 28 & 12.8 & 28 & 6.5 & $20-21$ & 54.9 & 12 \\
\hline Slovenia & 41 & 8 & 45.9 & 15 & 12.4 & 10 & 56.1 & 10 \\
\hline Slovakia & 9 & 24 & 31.8 & 22 & 19.1 & 2 & 67.6 & 4 \\
\hline Finland & 54 & 5 & 55.3 & $8-9$ & 9.3 & 15 & 43.7 & 22 \\
\hline Sweden & 58 & 4 & 54.2 & 10 & 6.9 & 19 & 55.1 & 11 \\
\hline United Kingdom & 27 & 14 & 60.2 & 5 & 20.8 & 1 & 59.0 & 8 \\
\hline
\end{tabular}

Source: Conducted by author based Science, Research and Innovation performance of the EU, 2018.

Results of evaluation of the set of economic and social criteria revealed that estimated countries rating coincides countries performance in human development index rating. This makes possible that set of criteria is appropriate for assessing the impact on combination of economic and social factors on processes of high 
technology development.

The impact of established economic and social factors was compared on four levels of assessment of high technology development: industrial (number of community design applications to the EUIPO per million population), business (number of innovative enterprises as a share of all enterprises), national (innovative turnover as a share of total turnover), international (exports medium- and high-technology products as a share of total product exports). Resulting matrix facilitates decision making process of choosing appropriate funding structure in order to improve country's performance on different stages of high technology development.

Table 6 estimates the reliability for five selected economic and social factors included in the final analysis. As the result, the number of community design applications to the EUIPO per million population (industrial approach of high technology sector development) has statistically significant relations with the research and development personnel and the number of persons employed in science and technology; similarly, number of innovative enterprises as a share of all enterprises (business approach) has statistically significant relations with the research and development personnel, and with the expenditure on research and development and the expenditure on social protection; only one significant factor was established for the exports of mediumand high-technology products as a share of total product exports (international approach) the share of GERD financed by business enterprise. There is important to note that the innovation turnover as a share of total turnover representing national approach in the process of high technology sector's development has no significant correlations with the established economic and social factors.

Table 6 Estimation of Correlation between Multiple Indicators and Attributes of Evaluation

\begin{tabular}{|c|c|c|c|c|c|c|c|c|}
\hline \multicolumn{2}{|l|}{ Criteria } & a) & b) & c) & d) & e) & f) & g) \\
\hline \multirow{2}{*}{$\begin{array}{l}\text { Community design } \\
\text { applications to the } \\
\text { EUIPO per million } \\
\text { population }\end{array}$} & $\mathrm{r}$ & 0.2445 & 0.2999 & 0.2498 & 0.0879 & -0.2339 & 0.5318 & 0.5799 \\
\hline & $\mathrm{t}$ & 1.2859 & 1.6029 & 1.3153 & 0.4502 & 1.2266 & 3.2022 & 3.6293 \\
\hline \multirow{2}{*}{$\begin{array}{l}\text { Number of innovative } \\
\text { enterprises as a share of } \\
\text { all enterprises }(\%)\end{array}$} & $\mathrm{r}$ & 0.6047 & 0.5316 & 0.3666 & -0.2790 & -0.1408 & 0.7598 & 0.3627 \\
\hline & $\mathrm{t}$ & 3.8715 & 3.2007 & 2.0094 & 1.4814 & 0.7251 & 5.9595 & 1.9847 \\
\hline \multirow{2}{*}{$\begin{array}{l}\text { Innovation turnover as a } \\
\text { share of total turnover } \\
(\%)\end{array}$} & $\mathrm{r}$ & 0.2175 & 0.0466 & 0.1896 & -0.2358 & -0.2055 & 0.2141 & 0.0122 \\
\hline & $\mathrm{t}$ & 1.1364 & 0.2381 & 0.9845 & 1.2372 & 1.0705 & 1.1179 & 0.0622 \\
\hline \multirow{2}{*}{$\begin{array}{l}\text { Exports of medium- and } \\
\text { high-technology products } \\
\text { as a share of total product } \\
\text { exports }(\%)\end{array}$} & $\mathrm{r}$ & 0.2446 & -0.0328 & 0.4575 & -0.2829 & -0.3130 & 0.0992 & 0.28849 \\
\hline & $\mathrm{t}$ & 1.2863 & 0.1675 & 2.6237 & 1.5041 & 1.6806 & 0.5083 & 1.5364 \\
\hline
\end{tabular}




\section{Conclusions}

Overview of theoretical statements and analysis of conducted scientific research confirmed the idea of four levels of assessment: industrial (community design applications to the EUIPO per million population), business (number of innovative enterprises as a share of all enterprises), national (innovation turnover as a share of total turnover), international (exports of medium- and high-technology products as a share of total product exports).

Results of evaluation of the set of economic and social criteria revealed that the estimated rating for those countries coincides their performance in human development. This makes it possible that the set of criteria is appropriate for assessing the impact on the combination of economic and social factors on processes of high technology development:

a) expenditure on research and development (percentage of GDP);

b) expenditure on social protection (percentage of GDP);

c) share of GERD financed by business enterprise sector (percentage of GDP);

d) share of GERD financed by government sector (percentage of GDP);

e) share of GERD on higher education sector (percentage of GDP);

f) research and development personnel (as percentage of total labour force);

g) persons employed in science and technology (as percentage of active population).

As a result, the number of community design applications to the EUIPO per million population (industrial approach of high technology sector development) has statistically significant relations with the research and development personnel and the number of persons employed in science and technology; similarly, the number of innovative enterprises as a share of all enterprises (business approach) has statistically significant relations with the research and development personnel, and with the expenditure on research and development and the expenditure on social protection; only one significant factor was established for the exports of medium- and high-technology products as a share of total product exports (international approach) the share of GERD financed by business enterprise.

Empirical evaluation of the theoretical guidelines, suggested as a method to assess the development process of the high technology sector of the European Union countries, has confirmed its validity for comprehensive evaluation of the development process of the high technology sector in different countries and regions worldwide.

\section{References}

Ball, D. A.; Lindsay, V. J. and Rose, E. L. (2008). "Rethinking the Paradigm of Service Internationalisation: Less Resource-intensive Market Entry Modes for Information-intensive Soft Services." Management International Review, Vol. 48, Issue 4, pp. 413-431. 
Carayannis, E. G., Rogers, E. M., Kurihara, K. and Allbritton, M. M. (1998). "High-technology Spin-offs From Government R\&D Laboratories and Research Universities." Technovation, Vol. 18, Issue 1, p. 1-11. Carter, S. and Jones-Evans, D. (2006). "Enterprise and Small Business: Principles, Practice and Policy (2nd ed.)." Strategic Direction, Vol. 25, Issue 5. Retrieved on October 10, 2019 from https://doi.org/10. 1108/sd.2009.05625eae.001.

D'Avenie, R. (1994). Hypercompetition. New York, USA: Simon \& Schuster, The Free Press Division.

Dunning, J. H. (1977). "Trade Location of Economic Activity and the MNE: A Search for an Eclectic Approach." The International Allocation of Economic Activity. Macmillan, London, United Kingdom.

Enders, J. (2004). "Higher Education, Internationalization and Nation-state: Recent Developments and Challenges to Governance Theory." Higher Education, Vol. 47, pp. 361-382.

Eurostat (2019). Government Expenditure on Social Protection. Retrieved on September 5, 2019 from https://ec.europa.eu/eurostat/statistics-explained/index.php?title=Government_ expenditure_on_social_protection\#Expenditure_on_.27social_protection.27.

Eurostat (2019). Human Resources in Science and Technology. Retrieved on September 5, 2019 from https://ec.europa.eu/eurostat/statistics-explained/index.php/Human_resources_ in_science_and_technology.

Eurostat (2019). R \& D personnel. Retrieved on September 5, 2019 from https://ec.europa.eu/ eurostat/statistics-explained/index.php?title=R_\%26_D_personnel\#Human_resources_in_ science_and_technology.

Eurostat (2019). Research and Development Personnel, by Sectors of Performance. Retrieved on September 5, 2019 from https://ec.europa.eu/eurostat/web/products-datasets/-/tsc00002.

Eurostat (2019). Science, Technology, Innovation. Retrieved on September 5, 2019 from: https://ec. europa.eu/eurostat/web/science-technology-innovation/data/database.

Hymer, S. H. (1960). "The Efficiency (Contradictions) of Multinational Corporations." American Economic Review, Vol. 2.

International Monetary Fund. World Economic Outlook Database, April 2019. Retrieved on September 5, 2019 from https://www.imf .org/external/pubs/ft/weo/2019/01/weodata/weorept.aspx?sy .

Johanson, J. and Vahlne, J. E. (1977). "The Internationalization Process of the Firm - A Model of Knowledge Development and Increasing Foreign Commitments." Journal of International Business Studies, Vol. 8 , Issue 1.

Leask, B. (2009). "Internationalisation, Globalization and Curriculum Innovation." Researching International Pedagogies, Vol. 1, pp. 9-26.

Loane S. (2005). "The Role of the Internet in the Internationalisation of Small and Medium Sized Companies." Journal of International Entrepreneurship, Vol. 3, Issue 4, pp. 263-277.

Longhi, S. and Nijkamp, P. (2007). "Economic Integration and Labour Markets: Ways forward. Contributions to Economics." in Regionalisation, Gowth and Economic Integration (Ed. George M. Korres), part I, pp. 3-23.

Mayer, T. and Ottaviano, G. I. P. (2008). "The Happy Few: The Internationalisation of European Firms. 
New Facts Based on Firm-level Evidence." Intereconomics, Vol. 43, Issue 3, pp. 135-148.

Park, S. (2001). "Globalisation and Local Innovation System: The Implementation of Government Policies to the Formation of Science Parks in Japan." Al \& society, Vol. 15, Issue 3, pp. 263-279.

Podvezko, V. (2011). "The Comparative Analysis of MCDA Methods SAW and COPRAS." Inžinerinė Ekonomika, Vol. 22, Issue 2, pp. 134-146.

Roberts, E. B. and Malone, D. E. (1996). "Policies and Structures for Spinning Off New Companies from Research and Development Organizations." Research and Development Management, Vol. 26, Issue 1, pp. 17-48.

Salter, B. (2009). "China, Globalisation and Health Biotechnology Innovation: Venture Capital and The Adaptive State." East Asian Science, Technology and Society: An International Journal, Vol. 3, Issue 4, pp. 401-420.

Science, Research and Innovation Performance of the EU (2018). Retrieved on September 5, 2019 from https://ec.europa.eu/info/sites/info/files/rec-17-015-srip-report2018_mep-web20180228.pdf.

Tsanova, I. and Havenith, R. (2019). Europe Is No Longer An Innovation Leader. Here's How It Can Get Ahead. Retrieved on 5 of September 2019 from: https://www. weforum.org/agenda/2019/03/europeis-no-longer-an-innovation-leader-heres-how-it-can-get-ahead/.

United Nations Development Programme (2018). Human Development Reports. Retrieved on 5 of September 2019 from: http://hdr.undp.org/en/composite/sHDI

Vernon, R. (1966). "International Investment and International Trade in the Product Cycle." Quarterly Journal of Economics, 80.

Wach, K. (2014). "Internationalisation and Globalisation as the Wider Context for Europeanisation Processes from the Macro- and Microeconomic Perspective." Horizons of Politics, Vol. 5, Issue 10, p. 11-30. Poland: Jesuit University Ignatianum in Krakow Institute of Political and Administrative Science.

Watt, A. (2009). "Distributional Issues in the Context of the Economic Crisis in Europe." Intereconomics, Vol. 44, Issue 2, pp. 82-89. 